\title{
Southern pine beetle-specific RNA interference exhibits no effect on model nontarget insects
}

\author{
Hannah Hollowell ${ }^{1} \cdot$ Lynne K. Rieske $^{1}$ D
}

Received: 30 June 2021 / Revised: 10 December 2021 / Accepted: 11 December 2021 / Published online: 4 January 2022

(c) The Author(s) 2022

\begin{abstract}
The efficacy and high specificity of the RNA interference pathway has prompted its exploration as a potential molecular management tool for many insect pests, including the destructive southern pine beetle, Dendroctonus frontalis Zimmermann, in which gene knockdown and mortality via double-stranded RNAs (dsRNAs) have already been demonstrated in the laboratory. The nucleotide sequence of dsRNAs requires an exact match of at least 16 nucleotides with the targeted messenger RNA to trigger knockdown of that gene. This allows vital genes in a target pest to be silenced and mortality induced while reducing the probability of adverse effects in nontarget organisms. However, prior to utilization in forest ecosystems, demonstration of the specificity of dsRNAs through laboratory bioassays evaluating potential nontarget effects on model insects is required for proper risk assessment analyses. Consequently, we evaluated three SPB-specific dsRNAs for lethal effects, sublethal effects (larval growth rate, adult emergence or adult fecundity), and relative gene expression in three model nontarget insects representing key functional guilds, including a predator, herbivore, and pollinator. The SPB-specific dsRNAs had no effect on survival of our nontarget insects. Additionally, no sublethal effects were found and the gene expression analyses corroborated bioinformatic analyses in finding no gene knockdown. Our findings support the high specificity of RNAi technology and provide support for its development and deployment for protection of conifer forests against SPB with minimal nontarget concerns.
\end{abstract}

Keywords RNA interference $\cdot$ Dendroctonus frontalis $\cdot$ dsRNA $\cdot$ Specificity $\cdot$ Hazard analysis

\section{Key message}

- RNA interference (RNAi) is a highly specific, cellular viral immune response that can be manipulated through the introduction of carefully designed double-stranded RNA (dsRNA).

- RNAi can cause rapid insect mortality when essential genes are targeted; it is being developed as an innovative tool for pest suppression.

- RNAi works in southern pine beetle (SPB) and using oral ingestion of dsRNAs targeting essential genes, kills insects quickly.

Communicated by Guy Smagghe.

Lynne K. Rieske

Lrieske@uky.edu

1 Department of Entomology, University of Kentucky, S225 Ag North, Lexington, KY 40546-0091, USA
- The specificity of selected SPB-specific dsRNAs was evaluated in feeding bioassays using model insects and evaluating lethal and sublethal effects, and when possible, gene expression and in silico analysis.

- No lethal, sublethal, or gene expression effects were found in the model insects evaluated.

- These findings corroborate the high specificity of RNAi technology and provide support for its development for protection of conifer forests against SPB with minimal nontarget concerns.

\section{Introduction}

Forests provide immeasurable benefits, both economic (Pye et al. 2011) and ecological (Tchakerian and Coulson 2011); implementing effective forest management strategies is essential to maintaining their function. In recent decades, temperate and boreal forests have experienced unprecedented pressure from bark beetle outbreaks (Coleoptera: 
Curculionidae, Scolytinae), reducing their economic value and threatening wildlife habitat, forest biodiversity, and their role in global carbon sequestration. Insecticides, while effective for bark beetle suppression, are impractical on a forest-wide scale (Grosman et al. 2009), and traditional bark beetle management has relied on silvicultural techniques to improve tree health and reduce susceptibility (Belanger et al. 1993; Nebeker 2004). However, the current management approaches are proving increasingly inadequate against outbreaking bark beetle populations, prompting investigations into novel mitigation strategies. Gene silencing through manipulation of the cellular RNA interference (RNAi) pathway is one such innovative approach.

RNAi-induced gene silencing takes advantage of an organism's endogenous defensive response to viral doublestranded RNA (dsRNA), triggering degradation of targeted genes and preventing production of corresponding proteins (Fire et al. 1998; Cerutti and Casas-Mollano 2006; Huvenne and Smagghe 2010). Introducing dsRNA targeting essential genes can cause mortality (Zotti and Smagghe 2015) and because the dsRNA must match at least a 16-nucleotide region of the target mRNA (Chen et al. 2021), this technology is highly specific (Agrawal et al. 2003; Whyard et al. 2009; Bachman et al. 2016). Manipulation of the RNAi pathway and its high specificity to target provides tremendous potential for insect pest management (Huvenne and Smagghe 2010; Zhang et al. 2013).

Many insects, especially coleopterans, are highly susceptible to RNAi (Palli 2014; Smagghe and Swevers 2014; Yoon et al. 2018), which has already been deployed for pest suppression in some agricultural (Zhang et al. 2017) and horticultural systems (Hunter et al. 2012). Genes that serve an integral function in western corn rootworm (Diabrotica virgifera) can be silenced using RNAi, causing larval mortality (Bolognesi et al. 2012). Development of effective delivery methods and demonstration of minimal nontarget effects have allowed this technology to move to the deployment stage (Bachman et al. 2013), and RNAi is now utilized as an additional tool in integrated management of western corn rootworm (Fishilevich et al. 2016). Efficacy of the RNAi pathway has been demonstrated in a number of tree-killing insect pests, including the emerald ash borer (Agrilus planipennis) (Zhao et al. 2015; Rodrigues et al. 2017b), Asian longhorned beetle (Anoplophora glabripennis) (Rodrigues et al. 2017a), and southern and mountain pine beetles (Dendroctonus frontalis and D. ponderosae) (Kyre et al. 2019, 2020).

The native southern pine beetle (SPB) is historically the most destructive forest insect pest in the southeastern USA (Nowak et al. 2008). SPB feed within the vascular cambium, causing tree mortality (Hain et al. 2011; Dodds et al. 2018). At innocuous levels, the oligophagous SPB target damaged or dying pines (Pinus spp.), but when populations reach outbreak levels, healthy trees are attacked, host preferences broaden, and widescale conifer mortality occurs leading to economic and ecological losses (Nebeker et al. 1992; Sullivan 2011). In recent years, the increasing severity of outbreaks, and unprecedented northward expansion of SPB's geographic range in response to warming temperatures, have prompted calls for more innovative, proactive management (Ungerer et al. 1999; Williams and Liebhold 2002; Dodds et al. 2018). The efficacy of RNAi in SPB (Kyre et al. 2019) opens up possibilities for its incorporation into integrated pest management programs, but developing viable delivery methods (Pampolini et al. 2020) and demonstrating specificity is essential to moving this technology to the deployment stage (Lundgren and Duan 2013).

Evaluating pest-specific dsRNAs for environment risks and potential negative effects on nontarget organisms is required for product registration and eventual commercialization (US Environmental Protection Agency 2014; Vélez et al. 2016; Christiaens et al. 2018; Haller et al. 2019; Mendelsohn et al. 2020; Romeis and Widmer 2020), and utilizing model organisms representing important functional guilds for nontarget assessments is an effective approach (Romeis et al. 2008; Whyard et al. 2009; US Environmental Protection Agency 2013). We evaluated lethal and sublethal effects, and gene expression, of dsRNAs designed to induce the RNAi pathway to kill SPB (Kyre et al. 2019) on model insects representing three functional guilds, including a predator, an herbivore, and a pollinator. Our goal is to demonstrate the specificity of the dsRNAs developed for gene silencing in SPB, to help advance this technology toward the deployment stage.

\section{Materials and methods}

\section{Nontarget species selection}

Nontarget insects were selected based on their significance as common representatives of important functional guilds (Bachman et al. 2013; Pampolini and Rieske 2020), and on the availability of published genome sequences to allow for bioinformatic analyses of potential homologous nucleotide sequences. Our model predator is the pink spotted lady beetle, Coleomegilla maculata (Coleoptera: Coccinellidae), our model herbivore the Colorado potato beetle (CPB), Leptinotarsa decemlineata (Coleoptera: Chrysomelidae), and our model pollinator the European honey bee, Apis mellifera (Hymenoptera: Apidae). 
Table 1 Target genes, dsRNA (including the T7 polymerase promoter sequences, in bold) and RT-qPCR primer sequences

\begin{tabular}{|c|c|c|c|}
\hline Gene & Primer & Primer sequence $\left(5^{\prime}-3^{\prime}\right)$ & $\begin{array}{l}\text { Ampli- } \\
\text { con size } \\
\text { (bp) }\end{array}$ \\
\hline \multirow[t]{4}{*}{ shi-shibire } & dsRNA-SHI F & TAATACGACTCACTATAGGGAGTTCGCCGTTGATGAAATC & \multirow[t]{2}{*}{370} \\
\hline & dsRNA-SHI R & TAATACGACTCACTATAGGGTCGAGCAGGGCTTTATGTCT & \\
\hline & qRNA-SHI F & TAGATCGGTGTCAGTTCCCC & \multirow[t]{2}{*}{86} \\
\hline & qRNA-SHI R & GCGAGCGCGTTTTCTATTAC & \\
\hline \multirow[t]{4}{*}{$h s p$ - heat shock protein } & dsRNA-HSP F & TAATACGACTCACTATAGGGACACGCACACTCGTTCTCAC & \multirow[t]{2}{*}{351} \\
\hline & dsRNA-HSP R & TAATACGACTCACTATAGGGTACGCGTACTCGCTGAAGAA & \\
\hline & qRNA-HSP F & TGCAGCAACTGGTCAAAGA & \multirow[t]{2}{*}{139} \\
\hline & qRNA-HSP R & TCTTTGGTCATGGGACGTT & \\
\hline \multirow[t]{4}{*}{ iap—inhibitor of apoptosis } & dsRNA-IAP F & TAATACGACTCACTATAGGGTTTCGTTTGATGCTCGACTG & \multirow[t]{2}{*}{379} \\
\hline & dsRNA-IAP R & TAATACGACTCACTATAGGGTCTTCGCCTGTCCTGTCTTT & \\
\hline & qRNA-IAP F & GTCCCGCTCATCCAGATAAA & \multirow[t]{2}{*}{109} \\
\hline & qRNA-IAP R & TTTTGCCTCTTTCGCACTTT & \\
\hline
\end{tabular}

\section{Synthesis of SPB-specific dsRNAs and control dsRNAs}

The efficacy of RNAi in SPB has previously been demonstrated; dsRNAs targeting three genes ( $s h i, h s p$, and iap) were evaluated, two of which were silenced ( $s h i$ and $h s p$ ) and induced SPB mortality (Kyre et al. 2019) and all three of which were silenced and mortality induced in the congeneric mountain pine beetle (Kyre et al. 2020). To assess the potential effects of silencing, these three target genes on selected nontarget insects and any associated lethal and sublethal effects, dsRNA for each gene were synthesized in vitro according to published protocols for use in feeding bioassays for the specified nontarget insects (Table 1).

SPB adults were reared from loblolly pine (P. taeda) bark collected from outbreak areas in the southeastern USA. RNA extracted from SPB adults was used to synthesize complementary DNA (cDNA) which was then used in a polymerase chain reaction (PCR) to amplify DNA using the above dsRNA primer sequences. The PCR thermocycler was set to $94{ }^{\circ} \mathrm{C}$ for 4 min to denature the cDNA, followed by 35 cycles of $94{ }^{\circ} \mathrm{C}$ for $30 \mathrm{~s}, 60{ }^{\circ} \mathrm{C}$ for $30 \mathrm{~s}$, and $72{ }^{\circ} \mathrm{C}$ for $45 \mathrm{~s}$ to anneal primers to target DNA, and finishing at $72{ }^{\circ} \mathrm{C}$ for $10 \mathrm{~min}$ to allow DNA polymerase to extend the copied strands of nucleic acids. The resulting PCR product was purified with a PCR purification kit (Qiagen Inc., Valencia, CA) and used as the template to synthesize dsRNA using the MEGAscript RNAi Kit (Ambion Inc., Foster City, CA). The reaction was placed in a dry bath at $37{ }^{\circ} \mathrm{C}$ for $14 \mathrm{~h}$ and then provided Turbo DNAse for another $15 \mathrm{~min}$ at $37^{\circ} \mathrm{C}$. The solution was then precipitated using sodium acetate at $0.1 \times$ per volume of reaction and $100 \%$ ethanol at $2.5 \times$ per volume of reaction. The precipitated solution was kept at $-20^{\circ} \mathrm{C}$ for a minimum of $2 \mathrm{~h}$ and then centrifuged at $14,000 \mathrm{rpm}$ for $30 \mathrm{~min}$ at
$4{ }^{\circ} \mathrm{C}$. Supernatant was removed, and dsRNA pellet was then washed with $75 \%$ ethanol and centrifuged at $14,000 \mathrm{rpm}$ for 15 min at $4{ }^{\circ} \mathrm{C}$. Supernatant was again removed, and dsRNA pellet was allowed to dry completely before being resuspended in deionized nuclease-free water. The dsRNA solution was checked for purity using gel electrophoresis and a spectrophotometer (Nanodrop Technologies, Wilmington, DE). The dsRNA was then diluted to concentrations specific to each nontarget insect.

\section{Bioassays}

Model insects were fed an SPB-specific dsRNA targeting the genes $s h i, h s p$, or iap, or a negative control ( $g f p$ ) for three days using protocols adapted from Pampolini and Rieske (2020). The $g f p$ gene, which encodes for production of green fluorescent protein, does not exist in the genomes of insects and cannot be silenced and should thus demonstrate no effect on insects. For a positive control, either a species-specific dsRNA documented to cause mortality or a chemical control (potassium arsenate) was used (Romeis et al. 2011). Each insect received $10 \mu \mathrm{g}$ of dsRNA each day for three days and was evaluated for survival. The predator and herbivore were also assessed for relative growth, adult emergence, or fecundity. Each assay was replicated three times for each model nontarget species. After three days of dsRNA exposure, a subsample of three insects from each treatment was collected for gene expression analysis.

\section{Model predator-pink spotted lady beetle}

Spotted lady beetle second instar larvae obtained commercially (Insect Lore, Shafter, CA) were divided into five 
treatments, including SPB-specific dsRNAs (dsSHI, dsHSP, and dsIAP), the negative control (dsGFP), and a dsRNA positive control (dsVATP) (Yang et al. 2015). Silencing the $v$-atpase gene causes significant mortality in related lady beetle species Adalia bipunctata and Coccinella septempunctata at concentrations of $2 \mu \mathrm{g} / \mu \mathrm{l}$ (Haller et al. 2019). SPB-specific dsRNA and control treatments were administered at a concentration of $2 \mu \mathrm{g} / \mu \mathrm{l}$, with $5 \mu \mathrm{l}$ per larva daily for 3 days pipetted onto small balls of autoclaved cotton ( $1 \mathrm{~mm}$ diameter). There were 24 larvae per treatment, for a total of $N=120$ larvae per replicate for 3 replicates. Larvae were placed in $0.5 \mathrm{ml}$ microcentrifuge tubes with the treated cotton; treatments were replenished daily for 3 days. Larvae were then transferred to $35 \mathrm{~mm} \times 12 \mathrm{~mm}$ petri dishes and fed commercially obtained Lepidoptera eggs (Ephestia kuehniella; Beneficial Insectary, Guelph, ON, Canada), replenished as needed. Assays were held at $23{ }^{\circ} \mathrm{C}, 60-65 \%$ relative humidity, and 16:8 L:D. Mortality was evaluated daily, and a subset $(N=6$ per treatment) were weighed, and their weight gain and relative growth rate $\left(R G R=\frac{\left(\left(M_{2}-M_{1}\right) / M_{1}\right)}{t_{2}-t_{1}}\right.$; where $\mathrm{M}=$ mass; $\mathrm{t}=$ time) were calculated (McEwan et al. 2009).

Following larval development and pupation, emerging adults were sexed (Nichols and Neel 1974) and grouped together by treatment into $90 \mathrm{~mm} \times 15 \mathrm{~mm}$ petri dishes with Lepidoptera eggs ad libitum and oviposition substrate. Lady beetle eggs were collected from adult dishes daily, counted, and hatch rate (\%) per day was calculated. Fecundity was expressed by calculating average hatch rate per female. The bioassay was terminated after 100 days or when all females had died.

\section{Model herbivore-Colorado potato beetle}

Eggs were collected from laboratory-reared $\mathrm{CPB}$, reared to second instar, and weighed prior to use in bioassays evaluating SPB-specific dsRNAs (dsSHI, dsHSP, and dsIAP). The negative control was dsGFP, and the dsRNA positive control was dsACT, which causes significant second instar CPB mortality (Zhu et al. 2011). The dsRNAs were prepared at a concentration of $5 \mu \mathrm{g} / \mu \mathrm{l}$ with $2 \mu \mathrm{l}$ administered to each CPB larvae daily for the initial three days of the bioassay. To prepare feeding assays, leaf discs were cut from terminal leaves of greenhouse grown potato using a $12 \mathrm{~mm}$ diameter punch and treated with $1 \mu \mathrm{l}$ of $0.001 \%$ Triton (SigmaAldrich Co., St. Louis, MO), spread evenly across each leaf disc (Pampolini and Rieske 2020). Once dry ( $10 \mathrm{~min}), 2 \mu \mathrm{l}$ of dsRNA solution was administered to each leaf disc and allowed to dry before the leaf discs were placed in individual petri dishes (50 $\mathrm{mm} \times 15 \mathrm{~mm}$ dishes).

Second instar larvae $(N=20$ per treatment per replicate for 3 replicates) of approximately the same initial weight
$(5.1 \pm 0.14 \mathrm{mg})$ were placed into individual petri dishes with a treated leaf disc. Treated leaf discs were replenished daily for the first three days and then replaced with untreated excised leaves thereafter. Assays were held at $23^{\circ} \mathrm{C}$ at $60-65 \%$ relative humidity and 16:8 L:D. Mortality was evaluated daily. A subset of larvae ( $N=6$ per treatment) were weighed immediately after molting to the third instar and again following the molt to the fourth instar; weight gain and RGR were calculated as described above.

Following the molt to fourth instar, larvae were monitored daily until they entered the pre-pupal stage and ceased feeding (Wraight and Ramos 2015), at which point they were moved to individual $\sim 166 \mathrm{ml}$ cups with autoclaved cotton to provide a substrate in which to pupate. Moisture was maintained by misting the cotton lightly with distilled water every other day. Adult emergence was assessed daily, and the bioassay concluded when adult emergence ceased ( $\sim 35$ days following initiation of bioassay), and any remaining larvae or pupae were considered nonviable ( 4-7 per treatment per replicate) and were treated as such in the statistical analyses.

\section{Model pollinator-European honey bee}

Newly emerged $(<24 \mathrm{~h})$ adult European honey bees were collected directly from hive frames for use in assays (Tan et al. 2016). Assay dishes consisted of $100 \mathrm{~mm} \times 20 \mathrm{~mm}$ petri dishes with a $1 \mathrm{~cm}$ diameter access hole in the side to administer the treatments and feed the bees, and with several ventilation holes in the lid (Pampolini and Rieske 2020). Treatments were administered from a modified $1.5 \mathrm{ml}$ microcentrifuge tube containing 3 small holes near the tip, inserted through the hole in the side of the petri dish (Vélez et al. 2016).

Treatments included the SPB-specific dsRNAs (dsSHI, dsHSP, and dsIAP), the negative control (dsGFP), and a chemical positive control ( $0.5 \%$ potassium arsenate). For modified microcentrifuge tubes containing the SPB-specific dsRNAs, $100 \mu \mathrm{g}$ of dsRNA was added as $50 \mu \mathrm{l}$ of treatment at a concentration of $10 \mu \mathrm{g} / \mu \mathrm{l}$. Additionally $500 \mu \mathrm{l}$ of $50 \%$ sucrose solution was added to each tube. For the positive control, $50 \mu \mathrm{l}$ of $0.5 \%$ potassium arsenate was added to $500 \mu \mathrm{l}$ of $50 \%$ sucrose solution per microcentrifuge tube.

Each petri dish contained 10 adult bees, with 5 dishes per treatment per replicate $(N=50$ per treatment per replicate and 3 replicates). Dishes were placed in a growth chamber in complete darkness at $34^{\circ} \mathrm{C}$ and approximately $75 \%$ humidity. Following three days of dsRNA exposure, all dishes were maintained on 50\% sucrose solution until assay termination. Mortality was monitored daily until all bees had died ( 30 days). Dead honey bees were removed daily, and sucrose solution was replenished as needed (approximately every 2 days). 
Table 2 RT-qPCR primer sequences used in gene expression analysis for model insects

\begin{tabular}{|c|c|c|c|}
\hline Model & Gene & Primer Sequence $\left(5^{\prime}-3^{\prime}\right)$ & Reference \\
\hline \multirow[t]{4}{*}{ Predator (pink spotted lady beetle) } & vATPase & $\begin{array}{l}\text { F-AGATCTCTTTTCCCATGT } \\
\text { R-AGAGCATCTCGGCCAGAC }\end{array}$ & Yang et al. (2015) \\
\hline & $h s p$ & $\begin{array}{l}\mathrm{F} \text {-GCCGATGCGGAGAAGTATAAAG } \\
\mathrm{R} \text {-CGGCTTGCTTGAGTTGGAATA }\end{array}$ & Yang et al. (2015) \\
\hline & $16 s$ & $\begin{array}{l}\text { F-TTGAAGGGCCGCAGTATTT } \\
\text { R-AAGAAAGTCGTTCCCTCATCAA }\end{array}$ & Yang et al. (2015) \\
\hline & $18 s$ & $\begin{array}{l}\text { F-AAGACGGACAGAAGCGAAAG } \\
\text { R-GGTTAGAACTAGGGCGGTATCT }\end{array}$ & Yang et al. (2015) \\
\hline \multirow[t]{6}{*}{ Herbivore (Colorado potato beetle) } & $B-a c t$ & $\begin{array}{l}\text { F-GCACGAGGTTTTTCTGTCTAGTG } \\
\text { R-ATGTCATCCCAGTTGGTGATG }\end{array}$ & Zhu et al. (2011) \\
\hline & shi & $\begin{array}{l}\text { F-AACATTTCAGACCCGACGAC } \\
\text { R-AGCCGGAACCTTCTATCGTT }\end{array}$ & Pampolini and Rieske (2020) \\
\hline & hsp & $\begin{array}{l}\text { F-GCTCCTGATGGACGAATTGATA } \\
\text { R-CATGTCAGAGGGAGCAACAA }\end{array}$ & Pampolini and Rieske (2020) \\
\hline & iap & $\begin{array}{l}\mathrm{F} \text {-CAATGGCAGACCATCGAGAA } \\
\mathrm{R} \text {-GCCGTACAGTCCACAAGTATC }\end{array}$ & \\
\hline & $r p 4$ & $\begin{array}{l}\text { F-AAAGAAACGAGCATTGCCCTTCCG } \\
\text { R-TTGTCGCTGACACTGTAGGGTTGA }\end{array}$ & Zhu et al. (2011) \\
\hline & $r p 18$ & $\begin{array}{l}\text { F-TAGAATCCTCAAAGCAGGTGGCGA } \\
\text { R-AGCTGGACCAAAGTGTTTCACTGC }\end{array}$ & Zhu et al. (2011) \\
\hline \multirow[t]{5}{*}{ Pollinator (European honey bee) } & $\operatorname{shi}$ & $\begin{array}{l}\text { F-AGGAGGAGGAGGAGGAAACA } \\
\text { R-CTCGTCCGTCCATCATTTCT }\end{array}$ & Pampolini and Rieske (2020) \\
\hline & $h s p$ & $\begin{array}{l}\text { F-TGAAGGTGAACGTCCAATGA } \\
\text { R-GTGGTATTCCTCGTGGTGCT }\end{array}$ & Pampolini and Rieske (2020) \\
\hline & iap & $\begin{array}{l}\text { F-CCTGCATTTCCTAGTTCTTCCT } \\
\text { R-GATGTTCCGTTTGGCGTTTC }\end{array}$ & Not applicable \\
\hline & act & $\begin{array}{l}\text { F- TGCCAACACTGTCCTTTCTG } \\
\text { R-AGAATTGACCCACCAATCCA }\end{array}$ & \\
\hline & $r p 49$ & $\begin{array}{l}\text { F-GAGGCTATATTGGCGTTGGA } \\
\text { R-CTGCGCGTTCTCTTCTTCTT }\end{array}$ & \\
\hline
\end{tabular}

\section{Gene expression analysis}

Gene expression was analyzed for a subset of insects $(n=5$ per treatment) using RT-qPCR. RNA was extracted following three days of exposure and used to produce cDNA for each sample. Three replicates of each sample were utilized, and samples were assessed based on the mean $\mathrm{Cq}$ value. Using reference genes, values were normalized and relative gene expression could be assessed with the $2^{-\Delta \Delta \mathrm{Ct}}$ outlined in Livak and Schmittgen (2001). The genes were analyzed based on sequences available and the ability to construct effective RT-qPCR primer sequences for the genes evaluated in each model insect (Table 2).

\section{Bioinformatic analyses}

To assess potential sequence ove2rlap of the SPB-specific dsRNAs and gene sequences of our model nontarget insects, bioinformatic analyses were conducted utilizing published sequences from NCBI (Bachman et al. 2013). For each gene targeted by the SPB-specific dsRNAs, orthologs in each of the model nontargets were assessed for alignments using the nucleotide BLAST (BLASTn) function from NCBI using a sequence match threshold based on Chen et al. (2021), which requires exact matches of $\geq 16$ nucleotides or only one to two mismatches in $\mathrm{a} \geq 26$ nucleotide sequence. Complete coding sequences (cds) were used when available or were substituted by predicted sequences based on annotations from genes of closely related species when unavailable.

\section{Statistical analyses}

All analyses were performed using R statistical software (RStudio version 1.4.1106). For mortality data, logistic regressions were conducted using generalized linear models assuming binomial distributions and evaluated with a $\chi^{2}$ test to identify any significant differences among treatments, replicates, or treatment and replicate interactions. For significant results, a Tukey's Least Significant Difference post hoc test was conducted to identify the predictor that was significant. For larval weight gain of the model 
Table 3 Number of coding sequence (cds) matches of SPB-targeted genes to model nontarget sequences

\begin{tabular}{llll}
\hline SPB gene & Nontarget insect & Data source & $\begin{array}{l}\text { Num- } \\
\text { ber of } \\
\text { matches }\end{array}$ \\
\hline shi & C. maculata & Not available & - \\
& L. decemlineata & cds & 1 \\
& A. mellifera & predicted & 1 \\
hsp & C. maculata & cds $($ H. axyridis) & 2 \\
& L. decemlineata & cds & 10 \\
\multirow{4}{*}{ iap } & A. mellifera & cds & 4 \\
& C. maculata & partial cds (Coccinellidae) & 1 \\
& L. decemlineata & predicted & 0 \\
& A. mellifera & predicted & 1 \\
\hline
\end{tabular}

herbivore and predator, evaluated as the relative growth rate (RGR), data were assessed for homogeneity of variances using Levene's Test and for normality using the Shapiro-Wilk Test; if data met the requirements $(p<0.05)$ for both tests, RGR data were assessed using a two-tailed analysis of variance (ANOVA) and any significant findings were further evaluated using Student's t-tests. Data that did not meet the assumptions required for an ANOVA were assessed using the nonparametric Kruskal-Wallis Test, and significant results were further analyzed with a Wilcoxon Rank Sum Test. Adult fecundity data were assessed using a two-tailed ANOVA after evaluating for homogeneity of variances and normality. Adult emergence was evaluated using logistic regressions with generalized linear models assuming binomial distributions and also evaluated with a $\chi^{2}$ test to assess any significant difference between treatments or replicates. Relative gene expression was analyzed for a subset of insects from each bioassay using the $2^{-\Delta \Delta \mathrm{Ct}}$ method (Livak and Schmittgen 2001) and assessed for differences in relative expression with a two-tailed Student's

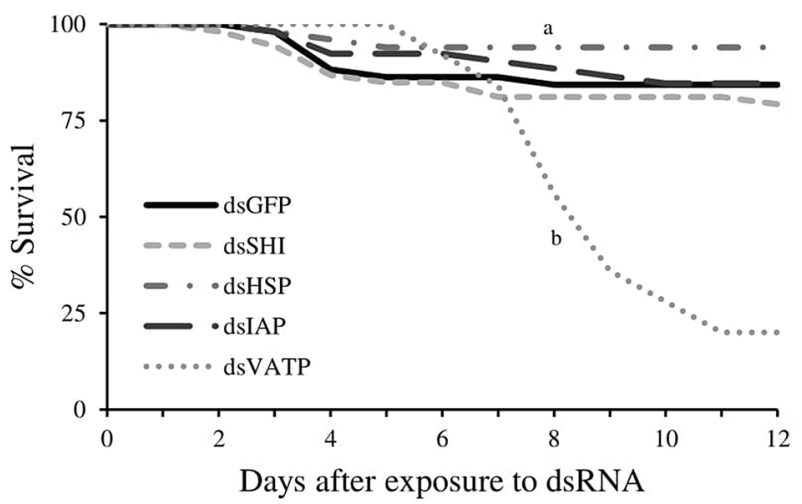

Fig. 1 Second instar lady beetle survival after ingestion of $10 \mu \mathrm{g} / \mathrm{d}$ for $3 \mathrm{~d}$ of SPB-specific dsRNAs (dsSHI, dsHSP, or dsIAP), a negative control (dsGFP), or a positive control (dsVATP) t-test to compare means between each gene of interest and the negative control, dsGFP.

\section{Results}

\section{Bioinformatic analysis}

The nucleotide BLAST results demonstrate that, of the available sequences, there is only one match per available nontarget sequence when the SPB genes shi and iap are evaluated in each of our nontarget species (Table 3). For the SPB gene $h s p$, matches are present in all three of the nontargets, and the number of matches ranges from 2 to 10 for the evaluated sequences.

\section{Model predator-pink spotted lady beetle}

\section{Lethal effects-Larval survival}

Second instar larvae exposed to SPB-specific dsRNAs exhibited $>80 \%$ survival until the prepupal stage ( $\sim 12$ days) for all treatments with no difference between treatments and the negative control $\left(\chi_{3,226}^{2}=2.73, P=0.44\right)$. The positive control demonstrating ingestion of the dsRNAs, dsVATP, exhibited $<35 \%$ survival to the prepupal stage, which was significantly lower than all other treatments $\left(\chi_{4,255}^{2}=41.63\right.$, $P<0.001$ ) (Fig. 1).

\section{Sublethal effects-Larval growth}

Second instar lady beetle larvae exposed to all treatments, including dsVATP, exhibited an average RGR of $\sim 38 \%$ of initial weight per day over the course of the third instar,

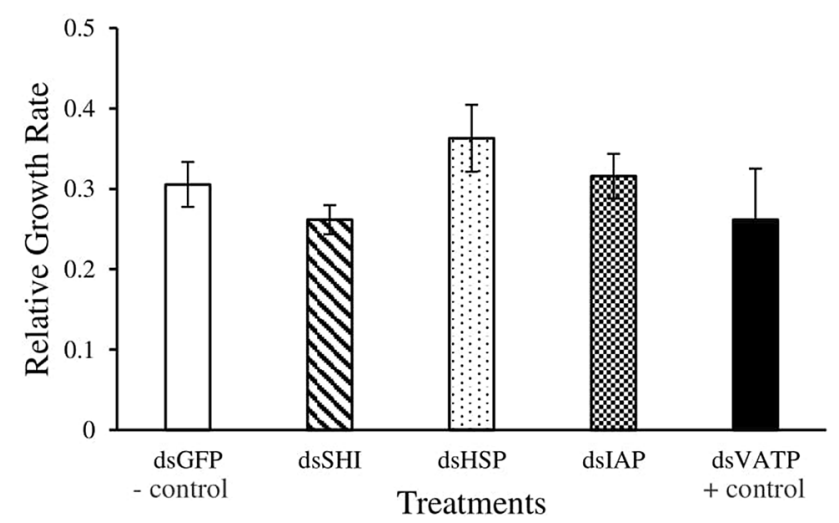

Fig. 2 Relative growth rate (RGR) of larval lady beetles fed on SPB-specific dsRNAs (dsSHI, dsHSP, or dsIAP), negative control (dsGFP), or positive control (dsVATP) shows no differences among dsRNA treatments 


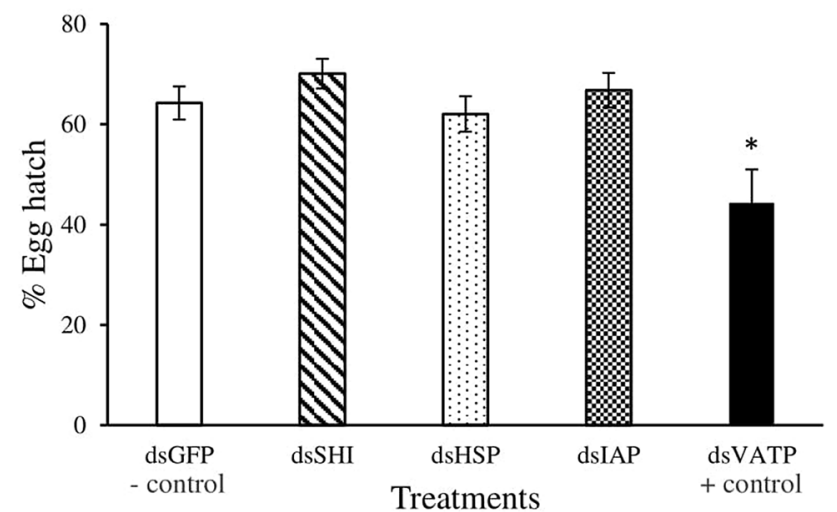

Fig. 3 Egg hatch for lady beetles fed SPB-specific dsRNAs (dsSHI, dsHSP, or dsIAP), negative control (dsGFP), or positive control (dsVATP) shows no differences among dsRNA treatments
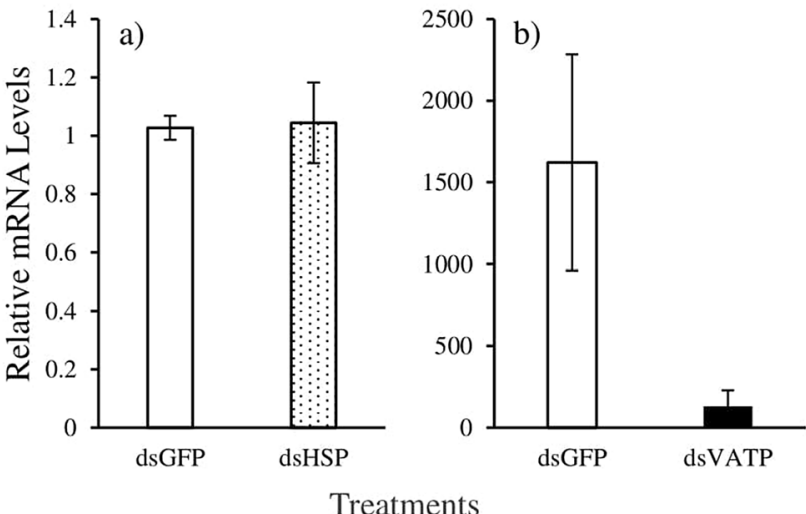

Fig. 4 Relative expression of the genes a $h s p$ and $\mathbf{b}$ the positive control (vATPase) relative to the negative control (dsGFP treatment) in second instar lady beetle larvae fed $10 \mu \mathrm{g} / \mathrm{d}$ of dsRNA treatments for 3 days shows no differences among dsRNA treatments; expression assessed with $v$ ATPase primers showed high standard error, obscuring potential differences

with time spent in that stage ranging from 3 to 6 days. For larval weight gain, expressed as RGR, there is no effect of the SPB-specific dsRNAs on development $\left(F_{4,39}=1.53\right.$; $P=0.21)$ (Fig. 2).

\section{Sublethal effects-Adult fecundity}

Following adult emergence, beetles were assessed for egg production and hatch rate for $100 \mathrm{~d}$. Egg hatch per clutch averaged $60 \%$ across all treatments, and there was no effect of the SPB-specific dsRNAs on fecundity $\left(F_{3,350}=\right.$ 2.16; $P=0.09)$; the only significant reduction in egg hatch occurred for the positive dsRNA control, dsVATP $\left(F_{4,383}=\right.$ 3.88; $P=0.004$ ) (Fig. 3).

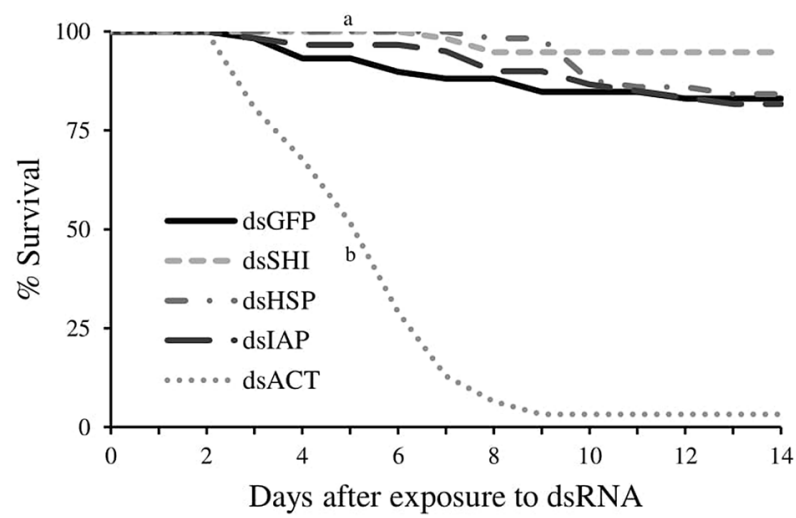

Fig. 5 Second instar CPB survival after ingestion of $10 \mu \mathrm{g} /$ day for 3 days of SPB-specific dsRNAs (dsSHI, dsHSP, and dsIAP), negative control (dsGFP), or positive control (dsACT)

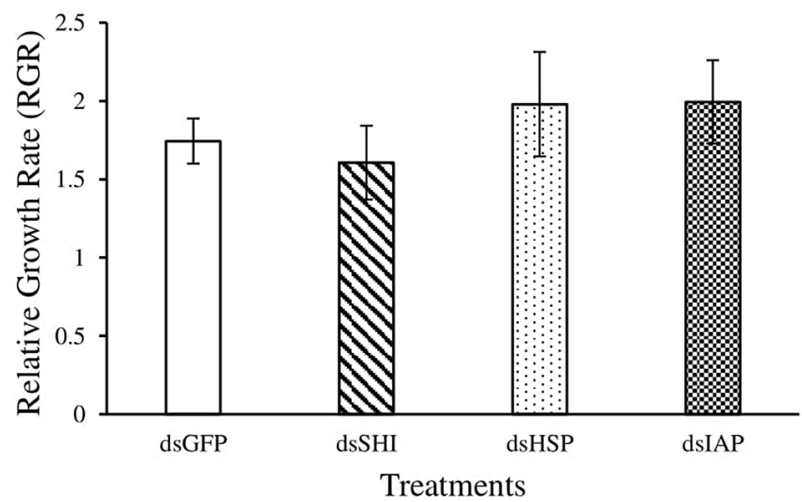

Fig. 6 Relative growth rate (RGR) of larval Colorado potato beetles fed SPB-specific dsRNAs (dsSHI, dsHSP, or dsIAP) or negative control (dsGFP) shows no differences among dsRNA treatments. The positive dsACT control was excluded from this analysis

\section{Gene expression}

Gene expression analyses, normalized with reference genes $16 s$ and $18 s$ (Yang et al. 2015), revealed no significant difference in relative expression of $h s p(P=0.47)$ in second instar lady beetle larvae fed on the SPB-specific dsRNA (Fig. 4), corroborating the bioassay results evaluating lethal and sublethal effects. Although the positive control (dsVATP) was assessed for relative gene expression $(P=0.11)$, the primers used for this analysis (Yang et al. 2015) yielded high standard error among both the negative control (dsGFP treated larvae) and the dsVATP treated larvae, leading to inconclusive results for relative expression of the positive control. 


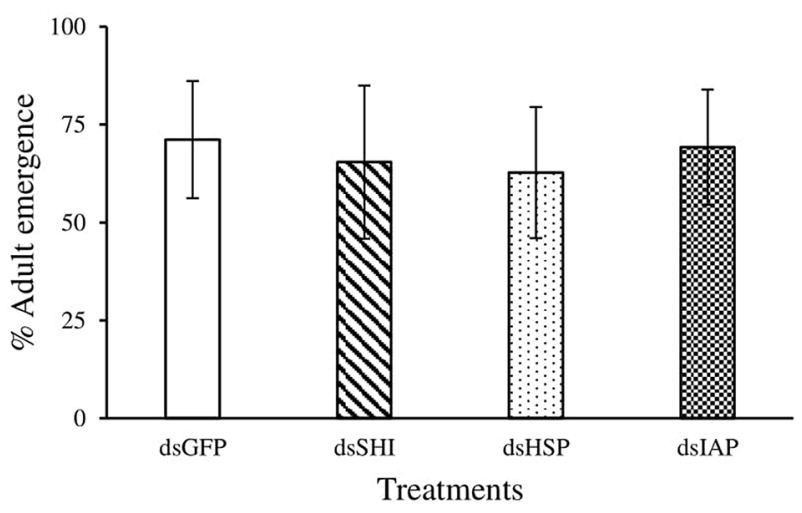

Fig. 7 Adult emergence of CPB that were fed SPB-specific dsRNAs (dsSHI, dsHSP, or dsIAP) or negative control (dsGFP) as second instar larvae and reared to adulthood on untreated potato leaves shows no differences among dsRNA treatments

\section{Model herbivore-Colorado potato beetle}

\section{Lethal effects-Larval survival}

For second instar larvae exposed to SPB-specific dsRNAs, survival to pupation ( $\sim 14$ days) was $>80 \%$ for all treatments except the positive control, and there was no difference among treatments and the negative control $\left(\chi_{3,229}^{2}=5.07\right.$, $P=0.16)$. The positive dsACT control showed significant decline in survival $\left(\chi_{4,259}^{2}=106.16, P<0.001\right)$, with $<5 \%$ of larvae reaching pupation (Fig. 5).

\section{Sublethal effects-Larval growth}

Data for larval growth of CPB had a non-normal distribution $(P=0.04)$ and were therefore analyzed with a nonparametric test. The subset of larvae evaluated from all treatments exhibited a RGR of $\sim 183 \%$ per day over the course of the third instar, requiring 2-5 days. Among the SPB-specific dsRNAs and the negative control (dsGFP), there is no difference between treatments $(P=0.59)$ (Fig. 6). None of the subset of larvae from the positive control treatment (dsACT) survived through the third instar, so no RGR was calculated for the positive control.

\section{Sublethal effects-Adult emergence}

Of the individuals exposed to SPB-specific dsRNAs that survived to pupation, $>55 \%$ successfully emerged as adults (Fig. 7), and there was no significant difference between SPB-specific dsRNAs and the negative control $\left(\chi_{3,202}^{2}=\right.$ 5.81, $P=0.12$ ). The positive control, dsACT, had no adult emergence; only three experimental larvae survived to the prepupal stage and none of those eclosed as adults.

\section{Gene expression}

There were no differences in relative expression of $s h i$ $(P=0.22), h s p(P=0.37)$, or iap $(P=0.39)$ in second instar CPB larvae exposed to SPB-specific dsRNAs for 3 days when normalized with reference genes $r p 4$ and $r p 18$ (Zhu et al. 2011) (Fig. 8). As expected, the positive dsACT control caused significant knockdown of act when evaluated

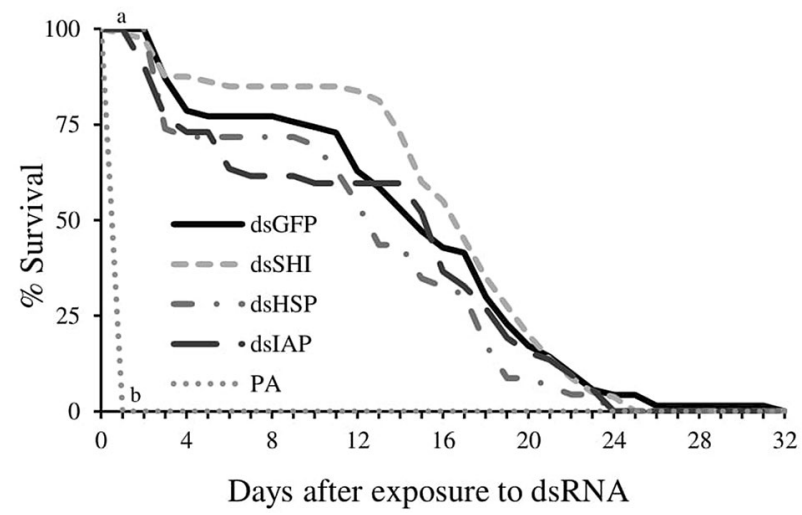

Fig. 9 Honey bee worker survival after ingestion of SPB-specific dsRNAs (dsSHI, dsHSP, and dsIAP), negative control (dsGFP), or positive potassium arsenate control (PA)
Fig. 8 Relative mRNA levels of $\mathbf{a} s h i$, $\mathbf{b} h s p$, and $\mathbf{c}$ iap genes showed no significant difference in second instar CPB larvae fed SPB-specific dsRNAs for 3 days, with gene knockdown only demonstrated with the d) act gene for larvae that received the positive dsRNA control (dsACT)

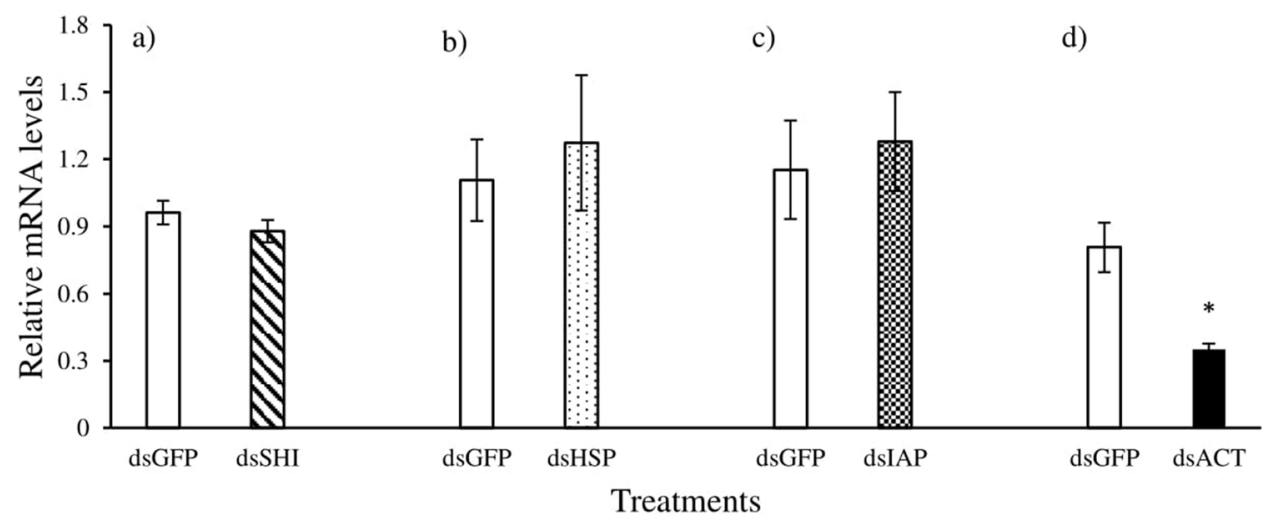




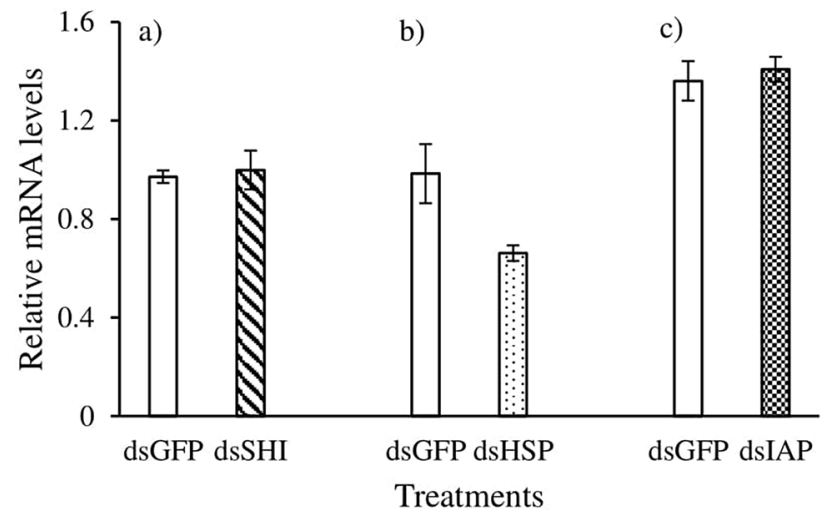

Fig. 10 Relative mRNA levels of a $s h i$, b $h s p$, and c iap genes showed no significant difference from the negative dsRNA control in honey bee workers fed SPB-specific dsRNAs

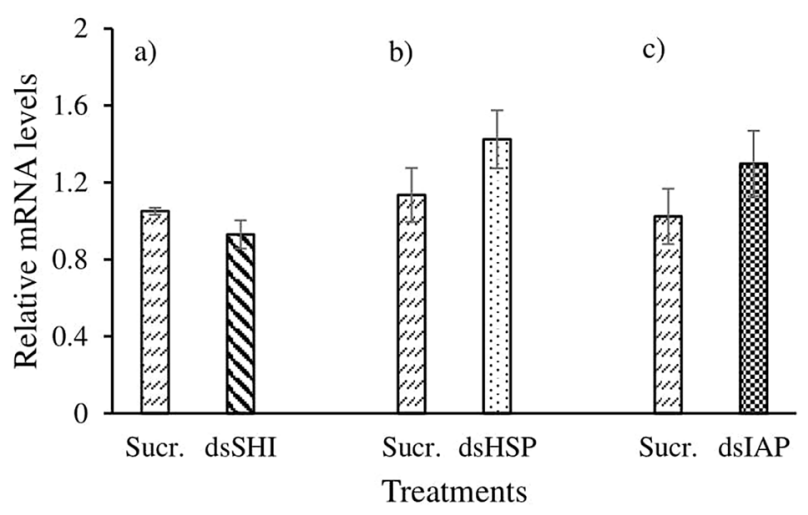

Fig. 11 Relative mRNA levels of a shi, b hsp, and $\mathbf{c}$ iap genes showed no significant difference from the negative sucrose control in honey bee workers fed SPB-specific dsRNAs

for relative gene expression ( $P=0.01)$ (Zhu et al. 2011). Although the bioinformatic analysis showed some potential matches in nucleotide sequence for $h s p$ in $\mathrm{CPB}$, the results of our gene expression analysis demonstrate no change in expression for $h s p$, or for any of the SPB-specific treatments, further supporting the findings of our bioassays.

\section{Model pollinator-European honey bee}

\section{Lethal effects-Honey bee worker survival}

Newly emerged adult workers exposed to SPB-specific dsRNAs were evaluated for $32 \mathrm{~d}$, until all bees had died. There was no difference in survival between the dsRNA treatments and the negative control $\left(\chi_{3,280}^{2}=3.75, P=0.29\right)$, whereas the positive potassium arsenate control caused significant mortality $\left(\chi_{4,248}^{2}=58.6, P<0.001\right)$, confirming that workers were ingesting the treatments (Fig. 9).

\section{Gene expression}

Relative gene expression, normalized with reference genes rp49 and act (Lourenco et al. 2008), demonstrated no differences in relative expression of shi $(P=0.41), h s p(P=0.06)$, or iap $(P=0.38)$ when compared to the negative dsRNA control (dsGFP) in adult honey bee workers (Fig. 10). Additionally, because honey bees have been noted to exhibit a generalized immune response to dsRNAs (Yang et al. 2018), relative expression was also assessed in relation to the sucrose negative control (Fig. 11); this also indicated no significant difference in relative gene expression for $s h i$ $(P=0.14), h s p(P=0.16)$, and iap $(P=0.17)$. These findings corroborate those of the bioassay, demonstrating no effect of the SPB-specific dsRNAs on this vital model pollinator.

\section{Discussion}

With the advent of new molecular management techniques, research into RNA interference and the high sequence specificity required to induce this pathway has allowed development of both effective and selective control of insect pests. Already this novel molecular approach has offered hope for managing populations of agricultural pests (Fishilevich et al. 2016) and been demonstrated as efficacious against the southern pine beetle (Kyre et al. 2019) and several other forest pests (Rodrigues et al. 2017a, 2018; Kyre et al. 2020). While laboratory assays have demonstrated the efficacy of oral ingestion of dsRNAs in SPB (Kyre et al. 2019), demonstrating its specificity and developing feasible methods of delivery are key steps to move this technology to the deployment stage (Bachman et al. 2013; Lundgren and Duan 2013; Romeis and Widmer 2020; Silver et al. 2021).

Here, we definitively demonstrate the specificity of dsRNAs targeting the genes $s h i, h s p$ and iap in southern pine beetle utilizing model insects from different functional guilds of ecological importance; this is a recommended approach for evaluating the specificity of dsRNAs (Environmental Protection Agency 2013) and offers broad insights into potential nontarget effects of this emerging technology (Lundgren and Duan 2013). To construct the most stringent analysis possible and because coleopterans are noted for their sensitivity to dsRNAs (Smagghe and Swevers 2014), we included two phylogenetically distant coleopterans in our evaluations: our model herbivore, a Chrysomelidae and model predator, a Coccinellidae. Of these, our model herbivore, $\mathrm{CPB}$, is phylogenetically closer to SPB than our model predator, as the Chrysomeloidea superfamily is more closely related to the Curculionoidea superfamily to which SPB belongs (McKenna et al. 2019). Our initial bioinformatic analysis, using a conservative threshold established by Chen et al. (2021), found minimum overlap of 
nucleotide sequences between the nontarget insects and the SPB-specific sequences, with the greatest overlap in the $h s p$ gene of the more closely related CPB. While bioinformatic analysis is insightful for generalized evaluations of potential nontarget effects, bioassays evaluating activity of dsRNA treatments on live insects are imperative to demonstrate specificity (Environmental Protection Agency 2013) and to confirm the lack of non-sequence dependent effects of dsRNA (Christiaen et al. 2018). The greater relatedness of CPB to SPB may have contributed to a greater overlap of nucleotides in the $h s p$ gene, but this overlap did not correlate with any lethal, sublethal, or gene expression differences for CPB.

Similarly, we found no lethal or sublethal effects of the SPB dsRNAs on our model predator, but the results of our gene expression analysis for the spotted lady beetle were less definitive. Although the positive control, dsVATP, was assessed for relative gene expression and showed a substantial reduction in relative mRNA levels, the primers we used (Yang et al. 2015) yielded high standard error among both the negative control (dsGFP-treated larvae) and the dsVATPtreated larvae, leading to a substantial but non-significant $(P=0.11)$ reduction in relative expression of the positive control. Limitations in insect availability prevented our ability to analyze the more ecological relevant Thanasimus spp., a primary predator in the SPB-pine system, but our data suggest that SPB-specific dsRNAs may not affect these essential predators.

Although phylogenetically distant, our model pollinator, the European honey bee, represents an imperiled species of enormous economic and ecological value (van Engelsdorp et al. 2009). While several studies have documented dsRNA sensitivity in honey bees, suggestive of a generalized immune response (Nunes et al. 2013; Vélez et al. 2016; Pampolini and Rieske 2020), we found no lethal effects or gene knockdown from our SPB-specific dsRNAs on our model pollinator. Further studies evaluating immunological responses in honey bees are warranted and should offer additional insights.

For toxicity studies with non-target arthropods, dsRNA exposures should exceed the maximum amount projected to be encountered in the environment (EFSA 2014). SPB experiences significant gene knockdown and mortality following a single exposure to dsRNA solutions of $2.5 \mu \mathrm{g}$ (Kyre, unpublished data). The experimental diets we used incorporated dsRNAs at quantities $\sim 12 \times$ higher than that causing mortality in SPB, over the course of three days of treatment $(5 \mu \mathrm{l}$ at $2 \mu \mathrm{g} / \mu \mathrm{l}$ for 3 days for both the spotted lady beetle and Colorado potato beetle, and $10 \mu \mathrm{g}$ for 3 days per honeybee). Regardless of concentration, we found no lethal or sublethal effects of SPB-specific dsRNA ingestion in our model nontarget insects.
Related studies evaluating specificity of dsRNAs have also found a generalized lack of nontarget effects on model insects, including those developed for western corn rootworm (Bachman et al. 2013) and emerald ash borer (Pampolini and Rieske 2020). While utilizing model insects may allow laboratory evaluations of dsRNA specificity on a range of functional guilds from various habitats, these findings also have implications for practical field applications of RNAi technology. Our model predator, the pink spotted lady beetle, could co-occur in southern pine ecosystems where SPB is common; laboratory evaluations of co-occurring species can grant insight into potential effects on organisms that might interact with dsRNA treatments under field conditions. Importantly, the lack of negative effects on our model predator suggests that predators in pine ecosystems are also unlikely to be affected by SPB-specific dsRNAs. As natural enemies play an integral role in regulating SPB populations at endemic levels, the lack of nontarget effects suggests that RNAi management strategies will not conflict with the natural enemy complex already functioning in pine ecosystems. The complementarity of RNAi technology to existing biological control efforts is an important consideration in evaluating its feasibility as a pest management strategy in other tree-killing pests (Pampolini and Rieske 2020). Further studies evaluating co-occurring pine-associates will add to the body of evidence demonstrating the specificity of SPBtargeted dsRNAs and its compatibility with pre-existing SPB population regulators.

Our findings in this study will help validate the feasibility of RNAi as an additional tool for suppression of southern pine beetle in pine ecosystems by ensuring the safety of this emerging technology for nontarget insects. Once the challenges associated with practical delivery are overcome, the efficacy and high specificity of RNAi to target could provide a management option that reduces the impact on beneficial or other nontarget organisms and complements the natural enemy complex already in the environment. The potential for use of RNAi in conjunction with current pest management techniques could allow a sustainable multi-faceted management approach utilizing silvicultural, biological, and molecular techniques that suppress pest populations while preserving beneficial species.

\section{Author contributions}

LKR and HH conceived the experiments; $\mathrm{HH}$ conducted the experiments; $\mathrm{HH}$ analyzed the results; $\mathrm{HH}$ and LKR prepared the manuscript. Both authors provided input and approved the manuscript.

Acknowledgements The authors thank Flávia Pampolini for support and advice with experimental design, and Kylie Bickler, Zachary 
Bragg, Holly Foster, Beth Kyre, and Mary Wallace for technical assistance in the greenhouse and the laboratory. Clare Rittschof and Reddy Palli provided insects for bioassays, and Aviv Brokman provided statistical support.

Funding This work was supported by USDA APHIS AP20PPQST00C06-PE-SA1-21, the University of Kentucky, and the Kentucky Agricultural Experiment Station under McIntire-Stennis 2352657000 , and is published with the approval of the director.

Availability of data and material Data will be made available in a free and publicly available depository.

\section{Declarations}

Conflict of interest The authors declare no conflict or competing interests.

Open Access This article is licensed under a Creative Commons Attribution 4.0 International License, which permits use, sharing, adaptation, distribution and reproduction in any medium or format, as long as you give appropriate credit to the original author(s) and the source, provide a link to the Creative Commons licence, and indicate if changes were made. The images or other third party material in this article are included in the article's Creative Commons licence, unless indicated otherwise in a credit line to the material. If material is not included in the article's Creative Commons licence and your intended use is not permitted by statutory regulation or exceeds the permitted use, you will need to obtain permission directly from the copyright holder. To view a copy of this licence, visit http://creativecommons.org/licenses/by/4.0/.

\section{References}

Agrawal N, Dasaradhi PV, Mohmmed A, Malhotra P, Bhatnagar RK, Mukherjee SK (2003) RNA interference: biology, mechanism, and applications. Microbiol Mol Biol Rev 67:57-685. https://doi.org/ 10.1128/MMBR.67.4.657-685.2003

Bachman PM, Bolognesi R, Moar WJ, Mueller GM, Paradise MS, Ramaseshadri P, Tan J, Uffman JP, Warren J, Wiggins BE, Levine SL (2013) Characterization of the spectrum of insecticidal activity of a double-stranded RNA with targeted activity against western corn rootworm (Diabrotica virgifera virgifera LeConte). Transgenic Res 22(6):1207-1222. https://doi.org/10.1007/ s11248-013-9716-5

Bachman PM, Huizinga KM, Jensen PD, Mueller G, Tan J, Uffman JP (2016) Ecological risk assessment for DvSnf7 RNA: a plantincorporated protectant with targeted activity against western corn rootworm. Regul Toxicol Pharmacol 81:77-88. https://doi.org/10. 1016/j.yrtph.2016.08.001

Belanger RP, Hedden RL, Lorio PL Jr (1993) Management strategies to reduce losses from the southern pine beetle. South J Appl for 17:150-154. https://doi.org/10.1093/sjaf/17.3.150

Bolognesi R, Ramaseshadri P, Anderson J, Bachman P, Clinton W, Flannagan R, Ilagan O, Lawrence C, Levine S, Moar W, Mueller G, Tan J, Uffman J, Wiggins E, Heck G, Segers G (2012) Characterizing the mechanism of action of double-stranded RNA activity against western corn rootworm (Diabrotica virgifera virgifera LeConte). PLoS ONE 7:e47534. https://doi.org/10. 1371/journal.pone.0047534

Cerutti H, Casas-Mollano JA (2006) On the origin and functions of RNA-mediated silencing: From protists to man. Curr Genet 50:81-99. https://doi.org/10.1007/s00294-006-0078-x
Chen J, Peng Y, Zhang H, Wang K, Zhao C, Zhu G, Palli SR, Han Z (2021) Off-target effects of RNAi correlate with the mismatch rate between dsRNA and non-target mRNA. RNA Biol. https:// doi.org/10.1080/15476286.2020.1868680

Christiaens O, Dzhambazova T, Kostov K, Arpaia S, Jogs MR, Urru I, Sweet J, Smagghe G (2018) Literature review of baseline information on RNAi to support the environmental risk assessment of RNAi-based GM plants. Euro Food Safe Auth 15(5):1424E. https://doi.org/10.2903/sp.efsa.2018.EN-1424

Dodds KJ, Aoki CF, Arango-Velez A, Cancelliere J, D'Amato AW, DiGirolomo MF, Rabaglia RJ (2018) Expansion of southern pine beetle into northeastern forests: management and impact of a primary bark beetle in a new region. J For 116:178-191. https://doi.org/10.1093/jofore/fvx009

EFSA (2014) European food safety authority international scientific workshop "Risk assessment considerations for RNAi-based GM plants." 4-5 June 2014, Brussels, Belgium. https://www.efsa. europa.eu/en/events/event/international-scientific-workshoprisk-assessment

Fire A, Xu S, Montgomery MK, Kostas SA, Driver SE, Mello CC (1998) Potent and specific genetic interference by doublestranded RNA in Caenorhabditis elegans. Nature 391:806-811. https://doi.org/10.1038/35888

Fishilevich E, Vélez AM, Storer NP, Li H, Bowling AJ, Rangasamy M, Worden SE, Narva KE, Siegfried BD (2016) RNAi as a management tool for the western corn rootworm. Diabrotica Virgifera Virgifera Pest Manag Sci 72(9):1652-1663. https:// doi.org/10.1002/ps.4324

Grosman DM, Clarke SR, Upton WW (2009) Efficacy of two systemic insecticides injected into loblolly pine for protection against southern pine bark beetles (Coleoptera: Curculionidae). J Econ Entomol 102:1062-1069. https://doi.org/10.1603/029. 102.0326

Hain FP, Duehl AJ, Gardner MJ, Payne TL (2011) Natural history of the southern pine beetle. In: Coulson RN, Klepzig KD (eds) Southern Pine Beetle II. Gen. Tech. Rep. SRS-140. Asheville, NC: U.S. department of agriculture forest service, Southern Research Station, 13-24.

Haller S, Widmer F, Siegfried BD, Zhuo X, Romeis J (2019) Responses of two ladybird beetle species (Coleoptera: Coccinellidae) to dietary RNAi. Pest Manag Sci 75:2652-2662. https://doi.org/10. $1002 /$ ps.5370

Hunter WB, Glick E, Paldi N, Bextine BR (2012) Treatment in trees and grapevines for insect pest suppression. Southwest Entomol 37(1):85-87. https://doi.org/10.3958/059.037.0110

Huvenne H, Smagghe G (2010) Mechanisms of dsRNA uptake in insects and potential of RNAi for pest control: a review. J Insect Physiol 56:227-235. https://doi.org/10.1016/j.jinsphys.2009.10. 004

Kyre BR, Rodrigues TB, Rieske LK (2019) RNA interference and validation of reference genes for gene expression analyses using qPCR in southern pine beetle. Dendroctonus Frontalis Sci Rep 9:5640. https://doi.org/10.1038/s41598-019-42072-6

Kyre BR, Bentz BJ, Rieske LK (2020) Susceptibility of mountain pine beetle (Dendroctonus ponderosae Hopkins) to gene silencing through RNAi provides potential as a novel management tool. For Ecol Manag 473(27):118322. https://doi.org/10.1016/j.foreco. 2020.118322

Livak KJ, Schmittgen TD (2001) Analysis of relative gene expression data using real-time quantitative PCR and the 2(-delta delta c(t)) method. Methods 25:402-408. https://doi.org/10.1006/meth. 2001.1262

Lundgren JG, Duan JJ (2013) RNAi-based insecticidal crops: potential effects on nontarget species. Bioscience 63(8):657-665. https:// doi.org/10.1525/bio.2013.63.8.8 
McEwan RW, Rieske LK, Arthur MA (2009) Potential interaction between invasive woody shrubs and the gypsy moth (Lymantria dispar), an invasive insect herbivore. Biol Invasions 11(4):10531058. https://doi.org/10.1007/s10530-008-9316-0

McKenna DD, Shin S, Ahrens D, Balke M, Beza-Beza C, Clarke DJ, Donath A, Escalona HE, Friedrich F et al (2019) The evolution and genomic basis of beetle diversity. Proc Natl Acad Sci USA 116(49):24729-24737. https://doi.org/10.1073/pnas.1909655116

Mendelsohn ML, Gathmann A, Kardassi D, Sachana M, Hopwood EM, Dietz-Pfeilstetter A et al (2020) Summary of discussions from the 2019 OECD conference on RNAi based pesticides. Front Plant Sci 11:740. https://doi.org/10.3389/fpls.2020.00740

Nebeker TE, Hodges JD, Blanche CA, Honea CR, Tisdale RA (1992) Variation in the constitutive defensive system of loblolly pine in relation to bark beetle attack. For Sci 38(2):457-466

Nebeker TE (2004) Advances in the control and management of the southern pine bark beetles. USDA Forest Service: General Technical Report SRS-75.

Nichols PR, Neels WW (1974) Sexing Coleomegilla maculata. J Econ Entomol 67:136-140. https://doi.org/10.1093/jee/67.1.136

Nowak J, Asaro C, Klepzig K, Billings R (2008) The southern pine beetle prevention initiative: working for healthier forests. J for 106:261-267

Nunes FMF, Aleixo AC, Barchuk AR, Bomtorin AD, Grozinger CM, Simões ZLP (2013) Non-target effects of green fluorescent protein (GFP)-derived double-stranded RNA (dsRNA-GFP) used in honey bee RNA interference (RNAi) assays. Insects 4:90-103. https://doi.org/10.3390/insects4010090

Palli SR (2014) RNA interference in Colorado potato beetle: steps toward development of dsRNA as a commercial insecticide. Curr Opin Insect 6:1-8. https://doi.org/10.1016/j.cois.2014.09.011

Pampolini F, Rieske LK (2020) Emerald ash borer specific gene silencing has no effect on non-target organisms. Front Agron 2:1-29. https://doi.org/10.3389/fagro.2020.608827

Pampolini F, Rodrigues TB, Leelesh RS, Kawashima T, Rieske LK (2020) Confocal microscopy provides visual evidence and confirms the feasibility of dsRNA delivery to emerald ash borer through plant tissues. J Pest Sci 93:1143-1153. https://doi.org/ 10.1007/s10340-020-01230-w

Pye JM, Holmes TP, Prestemon JP, Wear DN (2011) Economic impacts of the southern pine beetle. In: Coulson RN, Klepzig KD (eds) Southern Pine Beetle II. Gen. Tech. Rep. SRS-140. Asheville, NC: U.S. department of agriculture forest service, Southern Research Station, 213-222.

Rodrigues TB, Dhandapani RK, Duan JJ, Palli SR (2017a) RNA interference in the Asian longhorned beetle: identification of key RNAi genes and reference genes for RT-qPCR. Sci Rep 7:8913. https:// doi.org/10.1038/s41598-017-08813-1

Rodrigues TB, Rieske LK, Duan JJ, Mogilicherla K, Palli SR (2017b) Development of RNAi method for screening candidate genes to control emerald ash borer. Agrilus Planipennis Sci Rep 7:7379. https://doi.org/10.1038/s41598-017-07605-x

Rodrigues TB, Duan JJ, Palli SR, Rieske LK (2018) Identification of highly effective target genes for RNAi-mediated control of emerald ash borer. Agrilus Planipennis Sci Rep 8:5020. https://doi.org/ 10.1038/s41598-018-23216-6

Romeis J, Bartsch D, Bigler F, Candolfi MP, Gielkens MMC, Hartley SE, Hellmich RL, Huesing JE, Jepson PC, Layton R, Quemada H, Raybould A, Rose RI, Schiemann J, Sears MK, Shelton AM, Sweet J, Vaituzis Z, Wolt JD (2008) Assessment of risk of insectresistant transgenic crops to nontarget arthropods. Nat Biotechnol 26:203-208. https://doi.org/10.1038/nbt1381

Romeis J, Hellmich RL, Candolfi MC, Carstens K, De Schrijver A, Gatehouse AMR, Herman RA, Huesing JE, McLean MA, Raybould A, Shelton AM, Waggoner A (2011) Recommendations for the design of laboratory studies on non-target arthropods for risk assessment of genetically engineered plants. Transgenic Res 20:1-22. https://doi.org/10.1007/s11248-010-9446-X

Romeis J, Widmer F (2020) Assessing the risks of topically applied dsRNA-based products to non-target arthropods. Front Plant Sci 11:679. https://doi.org/10.3389/fpls.2020.00679

Silver K, Cooper AM, Zhu KY (2021) Strategies for enhancing the efficiency of RNA interference in insects. Pest Manag Sci 77(6):2645-2658. https://doi.org/10.1002/ps.6277

Smagghe G, Swevers L (2014) Editorial overview: pests and resistance - RNAi research in insects. Curr Opin Insect 6:iv-v. https://doi. org/10.1016/j.cois.2014.11.001

Sullivan BT (2011) Southern pine beetle behavior and semiochemistry. In: Coulson RN, Klepzig KD (eds) Southern Pine Beetle II. Gen. Tech. Rep. SRS-140. Asheville, NC: U.S. Department of Agriculture Forest Service, Southern Research Station, 25-50

Tan K, Dong S, Li X, Liu X, Wang C, Li J, Nieh JC (2016) Honey bee inhibitory signaling is tuned to threat severity and can act as a colony alarm signal. PLoS Biol 14(6):e1002496. https://doi.org/ 10.1371/journal.pbio.1002423

Tchakerian MD, and Coulson RN (2011) Ecological impacts of southern pine beetle. In: Coulson RN, Klepzig KD (eds) Southern Pine Beetle II. Gen. Tech. Rep. SRS-140. Asheville, NC: U.S. department of agriculture forest service, Southern Research Station, 223-234.

Ungerer MJ, Ayres MP, Lombardo MJ (1999) Climate and the northern distribution limits of Dendroctonus frontalis Zimmermann (Coleoptera: Scolytidae). J Biogeogr 26:1133-1145. https://doi. org/10.1046/j.1365-2699.1999.00363.x

United States Environmental Protection Agency (2013) White Paper on RNAi technology as a pesticide: problem formulation for human health and ecological risk assessment. EPA-HQ-OPP-2013-0485-0011

United States Environmental Protection Agency (2014) Meeting minutes of the FIFRA SAP meeting, January 28, 2014, 47-64.

Van Engelsdorp D, Evans JD, Saegerman C, Mullin C, Haubruge E, Nguyen BK, Frazier M, Frazier J, Cox-Foster D, Chen Y, Underwood R, Tarpy DR, Pettis JS (2009) Colony collapse disorder: a descriptive study. PLoS ONE 4(8):e6481. https://doi.org/10.1371/ journal.pone.0006481

Vélez AM, Jurzenski J, Matz N, Zhuo X, Wang H, Ellis M, Siegfried BD (2016) Developing an in vivo toxicity assay for RNAi risk assessment in honey bees, Apis mellifera L. Chemosphere 144:1083-1090. https://doi.org/10.1016/j.chemosphere.2015.09. 068

Whyard S, Singh AD, Wong S (2009) Ingested double-stranded RNAs can act as species-specific insecticides. Insect Biochem Mol Biol 39:824-832. https://doi.org/10.1016/j.ibmb.2009.09.007

Williams DW, Liebhold AM (2002) Climate change and the outbreak ranges of two North American bark beetles. Agric for Entomol 4:87-99. https://doi.org/10.1046/j.1461-9563.2002.00124.x

Wraight SP, Ramos ME (2015) Delayed efficacy of Beauveria bassiana foliar spray applications against Colorado potato beetle: impacts of number and timing of applications on larval and next-generation adult populations. Biol Control 83:51-67. https://doi.org/10. 1016/j.biocontrol.2014.12.019

Yang C, Pan H, Noland JE, Zhang D, Zhang Z, Liu Y, Zhou X (2015) Selection of reference genes for RT-qPCR analysis in a predatory biological control agent, Coleomegilla maculata (Coleoptera: Coccinellidae). Sci Rep 5:18201. https://doi.org/10.1038/srep1 8201

Yang D, Xu X, Zhao H, Yang S, Wang X, Zhao D, Diao Q, Hou C (2018) Diverse factors affecting efficiency of RNAi in honey bee viruses. Front Genet 9:384. https://doi.org/10.3389/fgene.2018. 00384

Yoon JS, Mogilicherla K, Gurusamy D, Chen X, Shankar CR, Chereddy R, Palli SR (2018) Double-stranded RNA binding 
protein, Staufen, is required for the initiation of RNAi in coleopteran insects. Proc Nat Acad Sci 15(33):8334-8339. https://doi. org/10.1073/pnas.1809381115

Zhang H, Li H, Miao X (2013) Feasibility, limitation and possible solutions of RNAi-based technology for insect pest control. Insect Sci 30:15-30. https://doi.org/10.1111/j.1744-7917.2012.01513.x

Zhang J, Khan SA, Heckel DG, Bock R (2017) Next-generation insectresistant plants: RNAi-mediated crop protection. Trends Biotechnol 35:871-882. https://doi.org/10.1016/j.tibtech.2017.04.009

Zhao C, Gonzales MAA, Poland TM, Mittapalli O (2015) Core RNAi machinery and gene knockdown in the emerald ash borer (Agrilus planipennis). J Insect Physiol 72:70-78. https://doi.org/10.1016/j. jinsphys.2014.12.002

Zhu F, Xu J, Palli R, Ferguson J, Palli SR (2011) Ingested RNA interference for managing the populations of the Colorado potato beetle, Leptinotarsa decemlineata. Pest Manag Sci 67:175-182. https://doi.org/10.1002/ps.2048

Zotti MJ, Smagghe G (2015) RNAi technology for insect management and protection of beneficial insects from diseases: lessons, challenges and risk assessments. Neotrop Entomol 44(3):197-213. https://doi.org/10.1007/s13744-015-0291-8

Publisher's Note Springer Nature remains neutral with regard to jurisdictional claims in published maps and institutional affiliations. 